\title{
Greening Universities with Mode 3 and Quintuple Helix Model of Innovation-Production of Knowledge and Innovation in Knowledge-Based Economy, Botswana
}

\author{
Shantha Indrajith Hikkaduwa Liyanage ${ }^{1}\left[\right.$ [D $\cdot$ Fulu Godfrey Netswera ${ }^{2}$
}

Received: 25 June 2019 / Accepted: 14 February 2021 / Published online: 4 March 2021

(c) The Author(s), under exclusive licence to Springer Science+Business Media, LLC part of Springer Nature 2021

\begin{abstract}
Most of the knowledge-based economies (KBEs) operate in a neoclassical economic model that does not recognize the importance of natural resources and sustainability beyond the market forces. In contrast, KBEs that rely on endogenous factors harmonize with the enlightened anthropocentrism for sustainable development with scientific and technical abilities to design the ecological system for infusing human values into nature. For example, the Quintuple Helix Model of Innovation. In this exploratory research, it was found that the conventional structure of universities in Botswana is unable to produce glocal green knowledge and innovation in their mainstream knowledge production process due to bureaucratism, rationalism, myths and ceremonies, isomorphism, and legitimacy whereas institutional logics and agency of social actors support for Paris Climate Agreement and 17 Sustainable Development Goals (SDGs). Hence, the Quintuple Helix Model with Mode 3-Knowledge production is used to redesign universities' conventional structures. This study perused two sources of data, document analysis, and interviews. Data collected from documents were analyzed by axial coding. After that, interview data from five internal stakeholders were collected based on priori codes, themes, and concepts developed with document analysis. They were thematically analyzed for triangulation. Finally, the theory was developed by induction underpinning with interpretive philosophy when redesigning universities' conventional structure. The proposed model designed is called "Green University System" to facilitate the production of glocal green knowledge and innovation for sustainable development with Mode 3 and Quintuple Helix model of innovation.
\end{abstract}

Keywords Knowledge-based economies (KBEs) · Quintuple helix model of innovation · Mode 3 knowledge production - Green university · Neo institutionalism · Green knowledge system

Shantha Indrajith Hikkaduwa Liyanage shantha.indrajith@bothouniversity.ac.bw

Extended author information available on the last page of the article 


\section{Introduction}

In the endeavor of achieving higher living standard and wellbeing of people by increasing the economic growth, it is apparent that a newer economic growth model, knowledge-based economies (KBEs), plays a vital role (Svarc \& Dabic, 2017) in all advanced industrialized economies and many developing economies around the world. These KBEs around the world are meant to be "economies which are directly based on the production, distribution, and use of knowledge and information" (OECD, 1996). Their ultimate objective is to achieve sustainable development by investing in human capital, technology, knowledge, and innovation to produce skilled, creative, innovative people and organizations with sustainability values and natural environment values.

In responding to the need of the hour, the Quintuple Helix model of innovation (Carayannis \& Campbell, 2010) by its fifth helix, natural environment, bridged the gap described above. The model is an extension of the Quadruple Helix model of innovation (Carayannis \& Campbell, 2009). It introduced the fourth helix, Mediabased and Culture-based Public and Civil Society, to embed and extend the Triple Helix model of innovation (Etzkowitz \& Leydesdorff, 1995). The Triple Helix model of innovation (THMI) contextualizes the three helices, Government, Industry, and University, shifting the production of knowledge and innovation from conventional Mode 1 to Mode 2 as theorized by Gibbons et al. (1994). The Quadruple Helix model of innovation (QuadHMI), by one of its four helices called Mediabased and Culture-based Public and Civil Society further shifted the production of knowledge and innovation from Mode 2 to Mode 3. The Quintuple Helix model of innovation (QuinHMI) by one of its helices called the natural environment paved the way for producing green knowledge and innovation, preferably Mode 3, to a new quality of life in KBEs.

After lapsing half of a decade since the introduction of QuinHMI, two universal top-down policies, Paris Climate Agreement and the 2030 Agenda for 17 Sustainable Development Goals with 169 targets and 300 plus indicators, endorsed QuinHMI. They mandated economies explicitly, including universities, to link their economic activities with nature, in other words, sustainable development. The vision and mission of these two universal packages and the QuinHMI were founded on the basis of enlightened anthropocentrism to bridge the gap made by the inability of the naturalness of the planet to be resilient for distortions caused by the business as usual. Hence, the success story of the sustainable world is dependent on the production of green knowledge and innovation, among other endogenous factors of KBEs. However, the nature and scope of the (green) knowledge meant for sustainability is to be understood in the context of glocal (global and local) knowledge economy and society (Carayannis \& Campbell, (2011); Carayannis \& Alexander, 2006; Carayannis \& von Zedtwitz, 2005).

Accordingly, the production of green knowledge and innovation is imperative for sustainable development in KBEs. Mode 3, or else Mode 2, is ideal for bridging scientific knowledge and non-scientific knowledge collaboratively to solve social problems. In contrast, the universities conventionally produce knowledge and 
innovation in pursuit of knowledge, Mode 1. They produce their scientific knowledge within autonomous disciplines in their mainstream. They do not contextualize knowledge to solve social problems. The boundaries between the universities and industry are not blurred (Gibbons et al., 1994). In other words, Mode 1 is not adequate to solve social problems. As a result, Mode 2 and Mode 3 have evolved combining scientific knowledge and social contexts. It is a reflexive knowledge production system with reverse communication. Namely, science speaks to society, and society speaks back to science (Nowotny et al., 2001).

Nevertheless, there is a lethargic transition of knowledge production from Mode 1 to Mode 2 and Mode 3 in Botswana (Onyancha \& Maluleka, 2011). The precise reason is structural issues. It did not dominate education and innovation even for a single year during the period from 1995 to 2010, according to the World Bank knowledge economy index (KEI) in African countries (Asongu et al., 2018). Further, the knowledge economy index was gradually falling from 5.07 in 1996 to 4.31 in 2012 (Knoema, 2019). The conventional structure of universities by governance, culture, curriculum, research, community outreach, internal operations, and the reporting system creates institutional barriers for producing green knowledge with Mode 2 or Mode 3. Isomorphism, legitimacy, institutional logic, and bureaucratization dominate to defend the conventional structure. These structural issues should be addressed in particular with the education system (universities) because universities are strongly interconnected for creating knowledge and innovation in KBEs (George, 2006). Each of the universities must be a credible institution which is a precondition to provide a stable structure for human interaction with less uncertainty for sustainable development in KBEs.

Further, the recent local and global developments warrant universities to actively contribute to economic growth moving away from the ivory towers' role. Botswana Vision 2036 has already been initiated to be a KBE. It ratified and domesticated the 2030 agenda for 17 SDGs. Botswana is committed by Nationally Determined Contribution to the Paris Climate Agreement. Consequently, a transition of knowledge production with QuinHMI from Mode 1 to Mode 2 or Mode 3 with the QuinHMI is imperative. The journey launched is evident by the Botswana Qualification Authority (BQA)'s vision that it is "To make Botswana nucleus of Global Competitive Knowledge and Skills".

Hence, this study is carried out to design a Green University System with contemporary social rules guided by Mode 03 with QuinHMI superior to THMI. The characteristics of Mode 3, pluralism, and diversity of knowledge and innovation systems lift the quality of developed or less developed society and economies from the current level to the next level. Further, Mode 3 allows and emphasizes the coexistence and co-evolution of different knowledge and innovation paradigms (Carayannis \& Campbell, 2010: 51-57), namely, six types of knowledge and innovation systems, Mode 1, Mode 2, Mode 3, THMI, QuadHMI, and QuinHMI (Carayannis et al., 2012). Even though all these six types of models can be used to create green knowledge and innovation at different levels of degrees, Mode 3 and QuinHMI enable the production of the highest quality of green knowledge and innovation needed for sustainable development. Consequently, a university reconfigured as a green university 
enables the production of green knowledge and innovation as "glocal green knowledge and innovation" with six types of knowledge systems.

Accordingly, the following research questions were framed in this exploratory research.

1. "Why are universities unable to create green knowledge and innovation for sustainable development in Botswana as a KBE?"

2. "Construct a blueprint in terms of Mode 3 with QuinHMI, which could be used to create green knowledge and innovation collaboratively with co-creation for sustainable development in Botswana as a KBE?"

However, the study is subject to three assumptions. One of them is that the prevailing knowledge production system will be evolved from Mode 1 to Mode 3 and QuinHMI to meet Botswana's 2036 vision. The second assumption is that the prevailing degree of democracy beyond constitutional democracy is adequate and will be further developed with vision 2036 to benefit the fourth helix of QuinHMI. The third assumption is that the proposed system to produce green knowledge and innovation with Mode 3 and QuinHMI includes the other four knowledge systems, Mode 1, Mode 2, THMI, and QuadHMI, because Mode 3 and QuinHMI is the broadest and superior knowledge production system.

\section{Managerial Implication of the Study}

A proposed design named "green university system," which integrates all essential elements of a green university, could be incorporated into the conventional structure of the universities so that they enable the production of high-skilled human capital with sustainable values to protect the ecology by being a green university in a KBE. Further, the universities designed for sustainable development enable collaboration, contextualization, and co-creation of green knowledge and innovation effectively and efficiently with all five helices. Furthermore, the proposed green universities enable the production of green knowledge and innovation in their mainstream process. Besides, universities that are not sustainable enable ascertaining their Status Quo and transform their universities into sustainable universities by adopting the proposed design.

In support, Di Nauta et al. (2015) point out that universities are accountable for developing the country in which it operates. They have to offer solutions by collaboration and co-create developing instruments, tools, and models for social issues. The QuinHMI as a tool collaborate with five contexts, in particular fourth and fifth helix, the best example of a democracy-based society in Taiwan, one of the most successful countries that controlled the COVID-19 epidemic. It was a collaboration between the industry and the government to supply face mask and manage the inventory's panic buying with an application program interface.

Further, Taiwan used (digital) democracy beyond constitutional democracy by bottom-up sharing of information, participatory collective actions, and hacktivism. 
When hacktivists work with open data projects to provide citizens with updated realtime inventory levels and the nearest pharmacy location to claim free masks without panic buying, the Taiwan government responded incorporating a bottom-up process instead of a top-down distribution system, reverse procurement (The Conversation, 2020). Further, COVID-19 has a direct relationship with the natural environment, the fifth helix of QuinHM. Mandal and Panwar (2020) argue that an increase of 1 ${ }^{\circ} \mathrm{C}$ of air temperature decreases $.86 \%$ of infected people. Chin et al. (2020) point out that $4{ }^{\circ} \mathrm{C}$ of air temperature for a long period can resist the virus, and they further point out that the virus cannot survive for more than $5 \mathrm{~min}$ when the air temperature is $70{ }^{\circ} \mathrm{C}$. World Health Organization (2020) expresses that sunlight and high air temperature could defeat the virus. Therefore, an interdisciplinary collaboration (including the natural environment of the society) is essential for the post-COVID-19 period as per a study of 32,365 nationally funded sustainability projects from the USA, EU, and Japan (Lee et al., 2020).

\section{The Outline of the Study}

After the introduction, together with the research problem, research questions, and the managerial implications of the study above mentioned, the next section/second section deals with the literature review under which theoretical framework is discussed to facilitate various principles of theories underpinned in this study. The third section is the methodology under which the research philosophy and the research design is discussed. The fourth section deals with the findings and discussion under which the research questions are first explored. After that, the findings and recommendations are uncovered. The fifth section is the conclusion that summarizes the findings and their significance. After that, the limitations of the study and the areas for future researches are stated. The final section is the list of references which strengthened the entire study.

\section{Literature Review}

\section{Sustainability in KBEs}

Most of the KBEs worldwide operate in some way or the other way of neoclassical economic models. The fundamental neoclassical economics' explanation does not directly support the concept of sustainability. Mulder and Van Den Bergh (2001) argue that mainstream neoclassical economics does not recognize the importance of natural resources and sustainable development beyond the market forces because neo-classical economic emphasizes quantitative changes as a closed system. Therefore, even though the natural resources are finite, a decrease in natural resources is offset by the increase of capital produced by the society in never-ending economic growth. Hence, Mulder and Van Den Bergh (2001) advocate the evolutionary traditions of environmental economics as an open system that interacts with the 
environment but emphasizes going beyond the technical changes by including the co-evolution of economy and environment, sustainable consumption, endogenous preference change, and climate change modeling.

However, Svarc and Dabic (2017) were skeptical that these neoclassical theories had offered any practical solutions to capitalize on the knowledge and or innovations in the absence of a policy-oriented approach. Nevertheless, their skepticism is now resolved by a framework, QuinHMI, and two universal policies, the Paris Climate Agreement and the 2030 agenda for 17 SDGs. Hence, the KBEs which rely on endogenous factors, technology, human capital, knowledge, and innovations as modern contributory factors of economic growth, harmonize with sustainability advocated (George, 2006) by the ecological economics bridging the gap between mainstream neoclassical economics and ecological economics.

The QuinHMI is an evolution from THMI and QuadHMI. The THMI was theorized by Etzkowitz and Leydesdorff (1995) who point out that three sub-systems, university, industry, and government, interact with each other and create knowledge for innovation fostering the economic and social development (Etzkowitz, 2003). In the interaction between university and industry, university as a support structure provides education to students transferred to the industry. The basic researches carried out by universities are transferred to the industry, which commercializes them. In the government and industry relationship, the government regulates the industry and market where necessary. Later, one more sub-system, media-based, and culture-based public and civil society was added into THMI and developed QuadHMI by Carayannis and Campbell (2009). The media-based and culture-based public and civil society mean the community. Ordinary people act temporarily or permanently, such as non-governmental organizations and associations with media. The democracy-based knowledge and innovation contributed by QuadHMI enable making a knowledge society. Such democracy is important because creativity comes not only within the workplace, profession, and classes but also from the public at large (Dubina et al., 2012). Further, Kolehmainen et al. (2016) argue that QuadHMI is superior to THMI because innovation processes are open for more various combinations of stakeholders.

After the development of QuadHMI, the most timely helix model as an extension of the Quadruple Helix Model, QuinHMI, was developed by Carayannis and Campbell (2010) by adding a natural environment as the fifth sub-system (Fig. 1). Accordingly, there are five sub-systems, education system, economic system, political system, media-based and culture-based public and Civil Society, and natural environment. These five sub-systems interact collectively $n$ a circular flow of knowledge processing with each other's knowledge. Grundel and Dahlstrom (2016) point out that the natural environment is a driver and the other four helices are actors in creating green knowledge and innovation. This five-helices model enables providing more innovations than the four-helix model. However, Leydesdorff (2012) advises being cautious when moving beyond three environments stating that such a model would require substantive specifications and operationalization. 


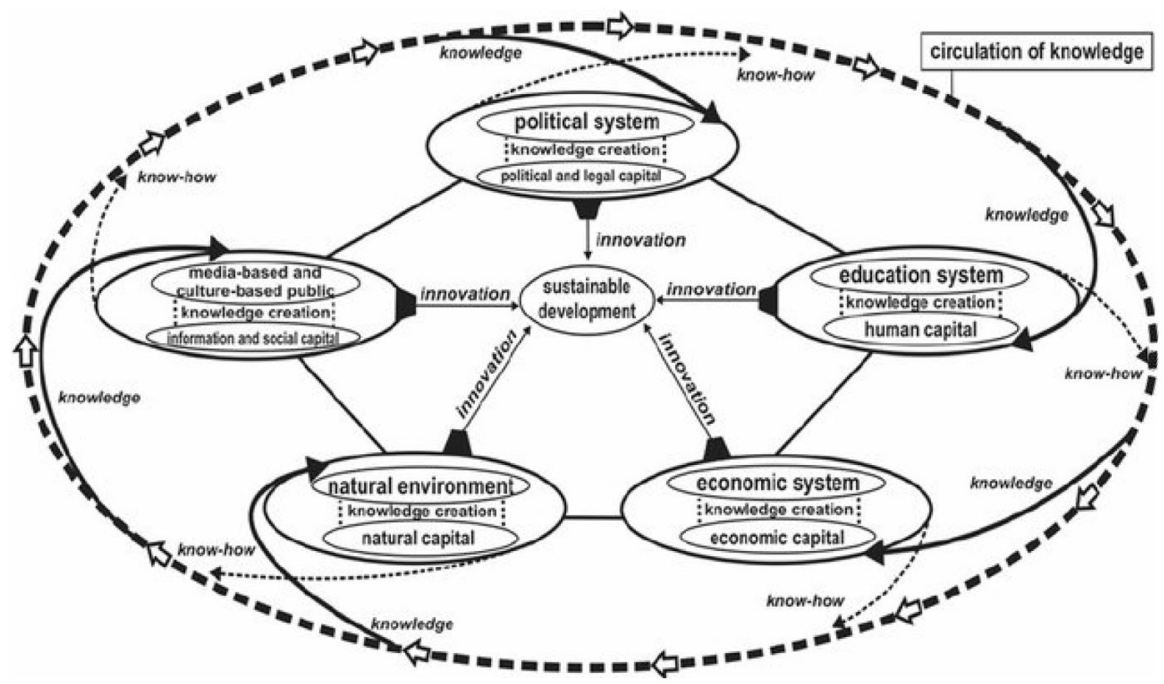

Fig. 1 Quintuple Helix model of innovation. Source: The Quintuple Helix model and its function (functions). Modified from Etzkowitz and Leydesdorff (2000), on Carayannis and Campbell (2006, 2009, 2010), and on Barth (2011). Carayannis et al. (2012) further explain by way of an example of how sustainable development could be achieved with targeted investment in the Education system (Fig. 2)

Accordingly, a high investment in the education system enables to produce high-skilled human capital with sustainable knowledge. While being innovative for sustainable development, high skilled human capital enters into the main circulation of knowledge and blends with the existing knowledge making knowledge greener. After that, sustainable values and ideas enter the economic system, enabling them to produce economic capital. While being innovative for sustainable development, a high-quality economy and new kind of free-market economy and new jobs and growth enter into the central circulation of knowledge, which mixes with the existing knowledge influenced by high-skilled human capital that enters into the natural environment system for protecting it which results in creating natural capital. While innovative for sustainable development, green know-how enters into the main knowledge creation, then blends with the previous outputs from previous sub-systems and enters into the media-based and culture-based public system as a new green lifestyle producing green information and social capital. While being innovative for sustainable development, the knowledge created exists as a new quality of life and then enters into the main circulation of knowledge. The quality of life then blends with the knowledge of the previous four sub-systems in the main circulation of knowledge and enters into a political system where knowledge creation produces political and legal capital. While being innovative for sustainable development, new ideas and solutions, programs, and laws enter into the main circulation of knowledge in a never-ending continuous improvement of quality of life on a sustainable planet. 


\section{Quintuple Helix Model and Neo Institutionalism}

As discussed above, education as a sub-system is expected to play a significant role in producing green knowledge and innovation. However, these universities that began with Bologna in the eleventh century have gradually evolved to today's universities inherited with a conventional structure to create knowledge in pursuit of knowledge, but not the knowledge and innovation for sustainable development, resolving social problems. Hence, QuinHMI in Botswana encounters challenges on how to produce highly skilled human capital with sustainable values in the process of creating green knowledge and innovation with the conventional structure at the micro-level. In this respect, the neo-institutional theory explains how the university, as an organization, resists green knowledge at the micro-level.

\section{The Rationality of Organization}

Neo institutionalism provides two reasons justifying the existence of organizations. One of them is the rationality of the organization. The rationality is the economic reason assigned by neo institutionalism for the existence and the role of the organization. It enables to internalize transaction costs and make rules for actions. These transaction costs include costs such as information costs, risks cost, waiting for cost, and the cost of retaliating or using a middleman (Hira \& Hira, 2010), but these transaction costs do not include the external cost such as anthropogenic greenhouse gas emissions and other negative externalities.

\section{Bureaucratization}

The second reason assigned by neo institutionalism for the existence and organization's role is the bureaucracy, which refers to a complex organization with multi-layered and complex processes. A bureaucratic organization is endowed with specialization and division of labor, hierarchical authority structures, rules and regulations, technical competence guidelines, impersonality and personal indifferences, and formal communication standards. Martin (2016) points out that many universities are more hierarchical and centralized, reduced local autonomy for departments, and centralized for a top-down approach.

\section{Isomorphism}

Isomorphism is a constraining process that makes one organization resemble other organizations in the organizational field. DiMaggio et al. (1983) argue that the causes of rationalization and bureaucratization but not them have changed since the middle of the last century. They point out that today's organizations are still becoming more homogeneous by bureaucratization as the common organizational form. However, the organizations' structural changes occur not by the necessity of efficiency or market competition but by isomorphism influenced mainly by the state and the profession. Universities as an organizational field are encouraged to be isomorphically requiring voluntary and statutory compliance with data requirements, 
research quantity, funding models, and standard quality rankings (Pratt, 2004). As a result, most universities are traditional universities that produce intellectuals and employable graduates in their traditional disciplines without paying attention to sustainable values.

\section{The Legitimacy of the Organization}

Meyer and Rowan (1977), Zucker (1977) and later contributions by Di Maggio and Powel (1983), and Scott (1987) elaborated the nature and extent of the structural elements of rationalized organizations that the organizational structures and practices are myths and ceremony adopted by organizations not because they are effective and efficient but because they give a sheen of legitimacy to those organizations (Alvesson \& Spicer, 2018). The legitimacy can be defined as "A generalized perception or assumption that the actions of an entity are desirable, proper or appropriate within some socially constructed system of norms, values, beliefs, and definitions" (Suchman, 1995 cited Ginzel, Kramer, \& Sutton, 1992; Nielsen \& Rao, 1987; Perrow, 1970). In this sense, universities have just started receiving a sheen of the legitimacy of the institutional logic of Quintuple Helix Model of Innovation in 2010, the 2030 agenda for 17 SDGs in 2015, and the Paris Climate Agreement in 2015.

\section{The Institutional Logics}

Are material practices of symbolic constructions? They are "taken for granted social prescriptions" (Battilana \& Dorado, 2010: 1420) or "Frames of reference that condition actors' choices for sense-making, the vocabulary they use to motivate actions, and their sense of self and identity" (Thornton et al., 2012:2). These institutional logics influence the decision-making of issues and solutions at the micro-level. However, an organization has to embrace multiple logics but not a single logic. They are competitive, but they may be cooperative, orthogonal, or blurred (Goodrick \& Reay, 2011; Waldorff et al., 2013). Since the institutional logics are not fixed among all the social actors, their application is subject to the interpretation of the organization (McPherson \& Sauder, 2013). When interpreting institutional logics, institutional actors have to balance complex institutional logics with the people and practices without contradictions (Battilana \& Dorrado, 2010).

\section{Institutional Change for Sustainability in Universities}

Universities require necessary changes to create green knowledge and innovation in KBEs. Sustainability, among other issues such as globalization and massification, challenges universities legitimately demanding necessary structural changes to accommodate sustainability in their role. Many scholars argue that the universities are complex organizations with distinctive characteristics such as complex governance structure and lack of a specific group responsible for necessary changes. Therefore, the change process is more challenging. Further, some scholars argue that "it is rather easier to change the world than to change the university" (Arnold, 2004; Baldwin \& 
Bauman, 2005; Blackmore \& Kandiko, 2012; Boyce, 2003; Eckel and Kezar, 2002; Merton, Froyd, Clark, \& Richardson, 2009 cited in Higgins \& Thomas, 2016).

However, a change in universities is also inevitable in the fast-paced world. Torraco (2005) argues that there are two distinct theoretical frameworks to change universities. "O" theory and "E" theory. Top management-driven change, E, is entirely different from the $\mathrm{O}$ theory's participatory nature. With expert consultants' help, the top management creates new strategies and structures to have systemic change for increasing the organization's economic value. Beer and Noria (2000 cited in Torraco, 2005) argue that both theories, $\mathrm{O}$ theory and $\mathrm{E}$ theory, can achieve a planned change of the organization and mix both systems to reduce costs and increase the benefits. Hence, the transformation of traditional universities to sustainable university in a knowledge-based economy is an innovation which requires an institutional change which can be achieved by theory $\mathrm{O}$ or theory $\mathrm{E}$.

\section{Methodology}

A critical review of the green university concept together with sustainability and sustainable development in the light of multidisciplinary, interdisciplinary, and transdisciplinary research articles first and then interviews was carried out. The critical review so carried out enlightened the phenomena that the universities enable playing a vital role in sustainable development. However, no pragmatic design theoretically founded can be found in this respect. In particular, no system is available to produce green knowledge and innovation with Mode 3 and QuinHMI.

In search of pragmatic design, the documents that belong to scientific discourse on sustainable universities were collected. The six databases of scholarly publishers of academic journals, Emerald Insights, EBSCOhost, ProQuest, STAR facility of Taylor Francis, and IGI Global, open-access databases, together with the web search engine and the database, Google Scholar, were accessed systematically to gather relevant research. The keywords to search the above databases were determined. The keywords such as Sustainable/Green University, Green Education, Green Research, Green Internal Operations/Green Campus, Community outreach, Corporate Governance, Organizational culture, Three Pillars of Sustainability, and Sustainability reporting were used. These keywords were run on several rounds with appropriate similar adjectives and nouns. For example, the adjective "green" was used to replace the word "sustainable." The noun "education" was replaced by the word "curriculum," namely, sustainable education as a green curriculum. The broad search terms abovementioned paved the way for identifying relevant research articles. Research articles that were duplicated in two or more databases were identified, and duplication was avoided. They were distilled systematically subject to quality check by sorting them on a spreadsheet to reduce the selection bias based on the model of the methodology developed by Gough et al. (2017).

After that, the research articles were analyzed by axial coding with Vivo codes. Accordingly, the codes which relate to the theory and pragmatic design were synthesized for related themes. Related patterns categorized them. These priori codes, themes, categories, and patterns were triangulated with Vivo codes of interviews. The 
interviews were administered among five stakeholders of universities, nine professors/ Dr, fourteen senior lecturers, eight academic managers (Deans/HODss), seven nonacademic managers, and nineteen undergraduates/postgraduates participated. The purposive sample participants who were subject to the saturation point principle represented five universities out of seven (four public and three private) universities in Botswana. These are teaching and research universities. Two of them are technology universities. The thematic analysis based on the grounded theory was used to analyze the interview data. The peer review also enhanced validity and reliability. The interviews and the access to all the documents available in the public domain were used ethically. Finally, the categories and their patterns with similar meanings were synthesized, paving the way for advocating a theoretical background to identify the eight essential elements of a green university which were integrated pragmatically in this exploratory research underpinning with interpretative philosophy.

\section{Findings and Discussion}

Tiba and Frikha (2018), who conducted a survey about resource curse mechanism among 22 African countries, including Botswana for a period 1990 to 2013, relate to the first research question of why universities in Botswana are unable to create knowledge and innovation for sustainable development. They pointed out that the weak institutional framework is a structural issue in Africa that weakens its economic growth. Universities in Botswana encounter several structural issues as barriers to the creation of green knowledge and innovation. One of them is the economic reason/rationality of the organization. The universities are not ready to internalize external costs such as social problems such as greenhouse gas emissions except one private university that internalized its greenhouse gas emission substantially by a medium-sized solar power project. Another reason is bureaucratism. The structures, rules and regulations, and hierarchical authority at Universities in Botswana are meant to create traditional disciplinary knowledge with Mode 1. The production of green knowledge and innovation are considered alien to their mainstream knowledge creation process. As Webber (1952: 181-82) points out, rationalization has created an iron cage in which humanity has been imprisoned until the last ton of coal is burnt unless there is a prophetic revival. He further contended that bureaucracy, which is the organizational manifestation of rationalist, is an efficient and powerful way of controlling people in an organization, and therefore once bureaucracy has been established, it cannot be reversed.

The policy documents such as vision, mission, values, and strategy are isomorphic among the universities to create knowledge and innovation in their traditional disciplines. The knowledge production process is based on Mode 1. Mode 1 is compatible with the linear model of innovation that universities conduct basic research. They are made available by publishing to the public, and after that, expect that firms pick up those research insights for application. The characteristics of Mode 2 were introduced by Gibbons et al. (1994). Nowotny et al. (2001, 2003, 2006 cited in Carayannis et al., 2016) point out the principles of Mode 2, that basic university researches produce knowledge in the context of an application, and they are 
transdisciplinary, heterogeneous, socially accountable, reflexive, diverse, and subject to quality control. Campbell and Carayannis (2013) explain the difference between Mode 1 and Mode 2, stating that it is a non-linear way of creating knowledge and innovation by coupling basic research not by "first then" but by "as well as" and "parallel" with the application and R\&D of basic research.

Another reason is the legitimacy of green knowledge and innovation. Unless some type of green knowledge evolved with the traditional knowledge system such as curricular for environmental studies offered by respective departments, none of the universities are ready to accommodate green knowledge and innovation, compromising traditional knowledge creation, which is carried on rather than myths and ceremonies than the effectiveness. In brief, the green knowledge system is still alien to the conventional knowledge system of the university.

These conventional structures of universities in Botswana do not actively provide for collaboration and co-creation with other helices of QuinHMI, industry, government, natural environment, and media-based and culture-based public for sustainable development. The existing structure deprives the application of QuinHMI of universities. Mode 3 knowledge production is alien for creating green knowledge and innovation in Botswana. Campbell and Carayannis (2013) point out that Mode 3 universities conduct basic researches in the context of an application. Carayannis et al. (2016) assert the importance of creative and innovative organizational context for Mode 3 so that it enables to combine and integrate different principles of knowledge production and their application by motivating diversity and heterogeneity for research and innovation (2016).

Hence, there is a need to develop a purposeful design called Green University System for greening a university. The proposed design could be incorporated into the existing conventional structures so that the universities enable the production of green knowledge and innovation in line with QuinHMI and Mode 3 knowledge production, the 2030 agenda for 17 SDGs, the Paris Climate Agreement, and the Nationally Determined Contribution of Botswana. They provide the institutional logic for the legitimate acceptance of green knowledge and innovation at universities. The proposed system facilitates the agency of institutional actors of the universities to interpret above institutional logics. Hence, it is required to reconfigure the conventional structure of universities in Botswana.

In this endeavor of developing a purposeful design called Green University System, the definition of Velazquez et al. (2006) is a good starting point. They define the sustainable university as "A higher educational institution, as a whole or as a part, is one that addresses, involves and promotes, on a regional or a global level, the minimization of negative environmental, economic, societal, and health effects generated in the use of their resources in order to fulfill its functions of teaching, research, outreach and partnership, and stewardship in ways to help society make the transition to sustainable lifestyles." This definition reflects that the sustainability prevails in a socioeconomic and environmental relationship, the three pillars of sustainability.

However, the sustainability practices by teaching, research, the university's ecological environment, and the community outreach with an appropriate balance of ecological, economic, and social sustainability are not necessarily adequate. 
Corporate governance, Organizational Culture, and Sustainability reporting are also imperatives. The thematic analysis and the axial coding identified eight imperatives as interrelated and interdependent concepts that should be aligned in a Green University System so that universities enable producing knowledge and innovation for sustainable development in their mainstream knowledge production process. The proposed system aims to design the most superior knowledge production system, Mode 3, and QuinHMI. In this respect, the constructivist approach is used to socially construct a green university as a social system that is not naturally predetermined by being independent of the researchers. Accordingly, eight knowledge clusters and their self-rationale and innovation networks are socially constructed in Table 1.

These eight knowledge clusters can co-exist, co-evolve, co-specialize, and coopetition among them and other helices as an advanced knowledge-based university (Carayannis et al., 2018), providing opportunities for green innovations. The innovation networks interact within the elements of the same knowledge cluster and with other knowledge clusters too. For example, the innovation network, "legitimacy for overall performance..." enables networking with the elements of the same knowledge cluster, green corporate governance, and other knowledge clusters such as green corporate culture. Moreover, with other helices too without inconsistencies and self-contradiction.

Drawing on the eight clusters above mentioned, further, the results allowed underpinning eight requisites of a green university: green corporate governance, green corporate culture, three pillars of sustainability, green curriculum, and green research, green community outreach, green internal operations, and green reporting. The adjective green emphasizes the importance of making the conventional component of a university ready to produce green knowledge and innovation. For example, corporate governance as a requisite of a conventional university cannot effectively contribute to producing green knowledge and innovation in its mainstream. On the other hand, green corporate governance contains green rules, green regulations, green procedures, green processes, and green practices that are aligned corporate governance system to contribute to the production of green knowledge and innovation directly.

\section{Requisite 01-Green Corporate Governance}

The system of governance of a university consists of rules, regulations, procedures, processes, and practices by which a corporate citizen is directed and controlled for achieving its vision and mission by way of goals, objectives, values, strategies, and leadership. In the context of Botswana, institutional logic mandates universities to be green. Botswana Qualification Authority's (BQA) vision provides that it is "To make Botswana nucleus of Global Competitive Knowledge and Skills." The King IV-Code of Corporate Governance, even-though not legislative in nature, is generally accepted practices of the corporate world (Institute of Directors, 2016). It advocates integrative thinking by being interconnected and interdependent with various factors that affect the organization's value creation. Integrative thinking includes not only stakeholder inclusivity such as the ecology and society but also integrated 
reporting also. The integrative reporting requires not only to confine to the fiscal bottom line but also to focus on its social and ecological impact also. King IV-Code of Corporate Governance places the sustainability better position than the other codes of Corporate Governance. Klettner et al. (2014) point out that the corporate governance system based on the Anglo-American legal system protects shareholders' interest as a priority. Europe and Japan's legal traditions give more rights to the employees and creditors. The Organization for Economic Cooperation and Development (OECD) in 1996 introduces a hybrid model to protect the diverse interests of stakeholders by converging both legal systems. OECD incorporates sustainability into corporate governance.

\section{Recommendation 01-Green Corporate Governance}

As discussed above, corporate governance is one of the imperative requisites of a greening university. It enables the provision of legitimacy to contextualize knowledge systems, Mode 2, Mode 3, Helix models, and all other green university requisites' legitimacy. The necessary "changes in governance structures and processes (green vision, green mission, green values, green objectives, green strategies, green leadership) can provide much greater overall leverage for transformation to sustainability than the implementation of specific sustainability initiatives" (Doppelt, 2010:96). Cartwright and Craig (2006) point out that aligning the leadership by a member of the strategic team/governing council who is accountable to the board/governing council is imperative because the commitment for sustainability in the governance arises not by the compliance or responsiveness but by the conviction for doing the right thing for creating green knowledge and innovation.

In this regard, it is recommended to set the self-rationale and innovation network as "The legitimacy for overall governance to create green knowledge and innovation with Mode 3 and QuinHMI." In this respect, it is required to develop a knowledge cluster called "green corporate governance" with necessary elements such as green governance structure (green rules, green regulations, green policies, green procedures, green processes), green strategy, and green leadership. These knowledge cluster elements interact with themselves, and the knowledge cluster interacts with other knowledge clusters creating interdependence.

\section{Requisite 02-Green Corporate Culture}

Universities are also organizations in society. They operate in a culture created by people involved there. Schein (1992) defines organizational culture as "the patterns of shared basic assumptions learned by the organization as it solves its problems of external adaptations and internal integration". These shared assumptions that are often implicit and operate at the sub-conscious level are deeply embedded and integrated into the organization and reflect its behavior. Hence, the values and beliefs required for people's behavior for sustainability can be communicated by the vision, mission statement underpinned with values intended to balance the organization's role to the market and society (Gaplin et al., 2015). When designing values, Thaman 
(2002) argues that sustainable development values seem to be greater if the values and goals of development are closer to the nation's community's values for which the sustainable development is meant.

\section{Recommendation 02-Green Corporate Culture}

The second critical requisite found in the above discussion is the Organizational culture of sustainability. It is recommended to set the self-rationale and innovation network as "The sense of comfort and belonging to create green knowledge and innovation with Mode 3 and QuinHMI." In this respect, it is required to develop a knowledge cluster called "green corporate culture" with necessary elements such as values, beliefs, assumptions, norms, artifacts, rituals, symbols, organizational stereotypes, and organizational heroes. These knowledge cluster elements interact with themselves, and the knowledge cluster interacts with other knowledge clusters creating interdependence.

In this regard, it is recommended to use the model created by Galpin et al. (2015) as a guideline. Their model is superior because the model incorporates multiple organizational processes instead of previous studies that contemplated a single stage, single discipline, and a single level of diverse perspectives of sustainability. Namely, their model explains that having set the direction for the organization's sustainability by mission, values, goals, and strategy requires integrating sustainability culture into the human resource practices, financial performance, and brand image of the organization. The employees' behavioral changes for reducing their own carbon footprint while averting the consumption of water, energy, and conservation of material used in their day-to-day life should also be detected. Such performance should be evaluated for recognition and reward, and reinforcement of sustainability values should be made where necessary. However, all these decisions and actions can be taken for granted in the absence of top management commitment. Schein (2010) argues that an organization's culture can be changed by a top-down approach, namely, by the diligent strategic management efforts that should be complemented by the bottom up.

\section{Requisite 03-Three Pillars of Sustainability}

Sustainability is a system which consists of sub-systems. There are two essential views to understand sustainability as a system. One of the views is proposed by Ott (2003). $\mathrm{He}$ argues that the economy is a sub-system of human society, a sub-system of the eco-system. Accordingly, these three systems can be illustrated as three concentric circles where the economic system is inside the human system, which is inside the ecosystem. The expansion of the economic system contracts the human system area, and an expansion of the human system contracts the eco-system area. The second view is popularly known as the Three Pillars of Sustainability or even the triple bottom line of sustainability expressed by the World Summit of the United Nations General Assembly (2005). This view is depicted by a Venn diagram consisting of three concentric circles 
for environmental sustainability, economic sustainability, and social sustainability with overlapping areas. The overlapping with each other denotes that these three pillars are not mutually exclusive. The common feature of both views is that sustainability is a systemic condition. These systemic interactions cause global warming, which is the product of systemic interactions (Smith, 2011), although the most acceptable view of sustainability is the second view, the three pillars of sustainability.

\section{Recommendation 03-Three Pillars of Sustainability}

The third imperative requisite of a green university found in the above discussion is the three pillars of sustainability, ecological environment, social environment, and economic environment (World Summit United Nations General Assembly., 2005). In this regard, it is recommended to set the self-rationale and innovation network as "reconciliation of the triple bottom line to create glocal green knowledge and innovation with Mode 3 and QuinHMI." In this respect, it is required to develop a knowledge cluster called "triple bottom line" with necessary elements such as ecological environment, social environment, and economic environment. These knowledge cluster elements interact with themselves, and the knowledge cluster interacts with other knowledge clusters creating interdependence.

In agreement with the three pillars of sustainability, Larson et al. (2013) point out that these three pillars' interdisciplinary nature requires to have sustainability practices with a tradeoff among them. When trading off, it is recommended to trade off the three pillars paying attention to local, regional, and global issues. Domesticated SDGs, Paris Climate Agreement, Nationally Determined Contribution should be taken into consideration. In this regard, it is to be noted that many sustainable practices focus on environmental or eco-efficiency (Fonseca et al., 2011; Lozano, 2006) while neglecting the social and cultural aspects of sustainability (Wright, 2010). Zhao and Zou (2015) point out that there can be a bias towards environmental sustainability. They further point out that holistic sustainability practices among the environment, economy, and society are required in a green university. Having traded off the three pillars, a green university enables carrying on its sustainable practices with green education, green research, green internal operations, and green community outreach to produce glocal green knowledge and innovation.

\section{Requisite 04-Green Education}

Green education refers to education for sustainability (Figs. 2 and 3). There is a stream of international appeal from higher education and universities to green the curriculum during the last five decades. The UNESCO's M.A.B. program in 1962, Club of Rome Report in 1971, Belgrade Charter in 1975, Tbilisi Intergovernmental conferences in 1977, International Meeting of Experts in Environmental Education of Paris in 1982, Moscow Conference in 1987, The World Conference on Environment and Development in Rio De Janeiro first time proposed 


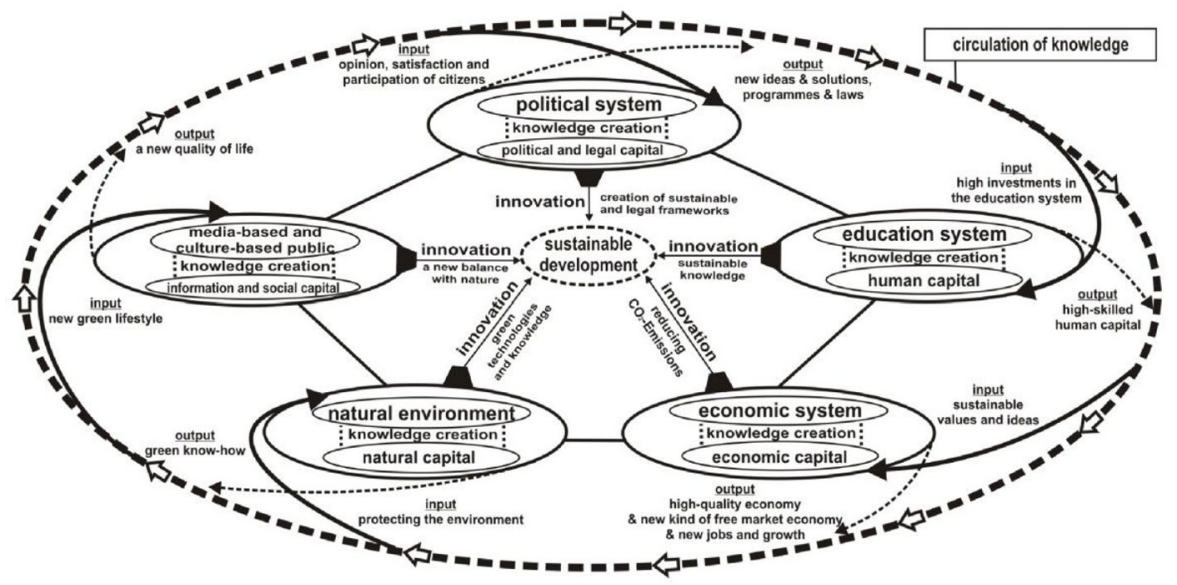

Fig. 2 Effects of investments in education for sustainability. Source: Carayannis et al. (2012)

Education for Sustainable Development (ESD) in 1992. Another landmark is the declaration of 2005 to 2014, the U.N. Decade of Education for Sustainable Development (DESD). The recent endorsement is in 2012 by the U.N. Conference on Sustainable Development confirmed the leadership role of higher education in ESD and now SDG 04: Quality education for ensuring inclusive and equitable quality education with life-long learning for all.

Fig. 3 Green university system. Source: Authors

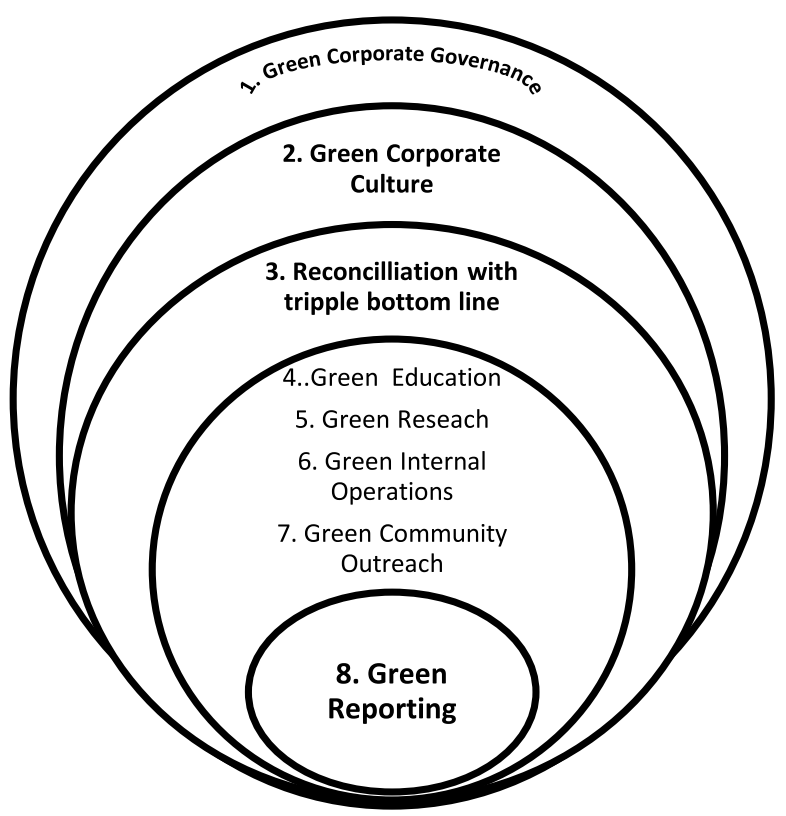




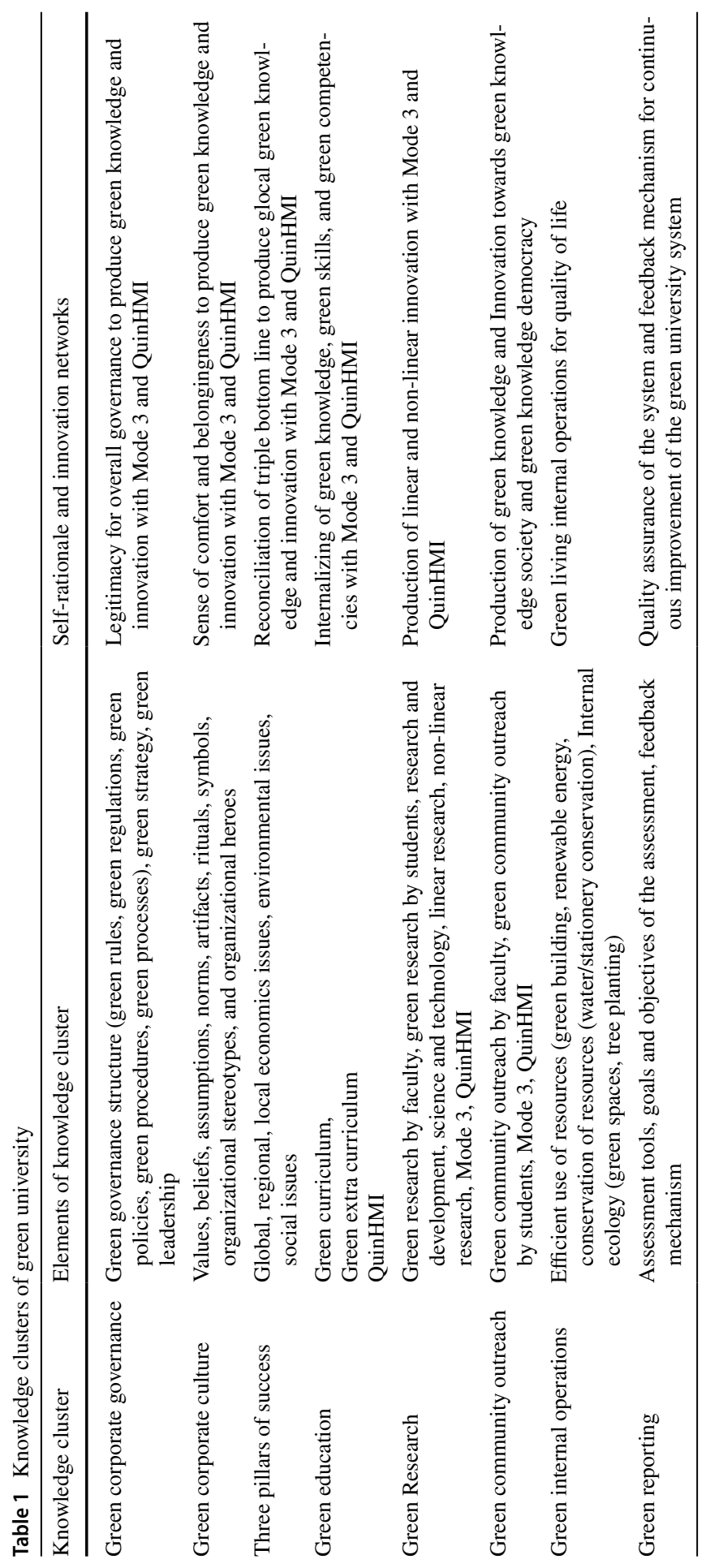




\section{Recommendation 04-Green Education}

Another imperative requisite in greening a university is green education. In this regard, it is recommended to set the self-rationale and innovation network as "internalizing of green knowledge, green skills, and green competencies with Mode 3 and QuinHMI." In this respect, it is required to develop a knowledge cluster called "green education" with necessary elements, green curriculum (pedagogy), and green extra curriculum (non-pedagogy). These knowledge cluster elements interact with themselves, and the knowledge cluster interacts with other knowledge clusters creating interdependence.

Green curriculum "through which students can internalize their awareness of environmental protection" (Zhao \& Zou, 2015) is the major component of education for sustainability development found in the discussion above. De Ciurana and Filho (2006) pointed out that the graduates who were taught sustainable criteria and values will carry out their professional activities, fostering sustainability. In greening the curriculum, it is recommended that the fundamental scientific understanding and sustainable development be taught mandatorily for all students until diverse, sustainable related curricula are gradually designed depending on the importance of such education (Zhao \& Zou, 2015). In this regard, few compulsory modules and few optional modules can be introduced by a pedagogical innovation to disseminate common knowledge to cultivate a typical intellectual conversation across all the academic departments to foster sustainable issues. Almost all the faculties can introduce various types of special sustainable development programs for in-depth knowledge of them. Faculties like engineering could take leadership to offer specialized programs for education for sustainability.

Apart from pedagogical innovations for education for sustainability development, the policy documents should demand non-pedagogical activities such as guest lecturers, activities, and projects involving students, faculties, communities, and other university stakeholders. However, in this endeavor, the factors such as complex structure, traditional disciplinary boundaries, ineffective governance, and the absence of shared vision at the universities face difficulties in achieving the goals of sustainability (Pollock et al., 2009) although universities are now mandated by SDG 04: Quality Education.

Hence, the green scientific knowledge together with other modes of knowledge, knowledge created by the industry, by the state/government, and media-based and culture-based public enjoy the democracy of knowledge-driven by the pluralism of knowledge, and these knowledge modes co-exist, co-evolve, and co-specialize with cross integration (Carayannis \& Campbell, 2009). Another critical aspect of the knowledge is knowledge levels, which can be categorized from least to the highest aggregation of knowledge as local, subnational, national, supranational, transnational, and global knowledge. Even though sustainability is a global issue, it should be addressed locally. Such green knowledge is termed glocal (global local) knowledge (Carayannis et al., 2012). 


\section{Requisite 05-Green Research}

Research is one of the primary tools which are used by the faculty of the university to enhance the prosperity of the country (Henkel, 2007; Mendivil, 2002; Dill, 1997 cited in Bessant et al., 2015). QuinHMI asserts the role of collaborative green research in the knowledge creation process (Carayannis, \& Campbell, 2010). Mensah et al. (2017) studied the challenges of collaborative research in an African country and identified some challenges within the university, such as inadequate infrastructure, limited funding, and delay in delivering support services.

Hence, a part of the faculty and students' researches should represent sustainable research. Another aspect of sustainability research at a university is that the faculty and students' sustainability research is also a criterion considered by many sustainability assessment tools (Jorge et al., 2016).

Since sustainability embraces multidisciplinary, interdisciplinary, and transdisciplinary characteristics, several domains are available for sustainable researchers, faculty, or students. Kajikawa (2008), who carried out content analysis of 35 research papers published in three core journals of sustainability during 2006 and 2007, developed inductively "ten domains of sustainability-related research: climate, biodiversity, agriculture, fishery, forestry, energy and resources, water, economic development, health, and lifestyles".

\section{Recommendation 05-Green Research}

Green research is another imperative requisite of a green university found in the above discussion. In this regard, it is recommended to set the self-rationale and innovation network as "non-linear green research with Mode 3 and QuinHMI." In this respect, it is required to develop a knowledge cluster called green research with necessary elements such as green research by faculty, green research by students, research and development, science and technology, linear research, non-linear research, Mode 3, QuinHMI. These knowledge cluster elements interact with themselves, and the knowledge cluster interacts with other knowledge clusters creating interdependence.

Linear innovation model of research in line with Mode 1 delays the application of basic research and their R\&D together with the technology life cycle. The non-linear innovation model goes with Mode 2 or Mode 3. Mode 2 is characterized by the application of basic research and its R\&D without delay. It possesses characteristics such as transdisciplinarity, heterogeneity, organizational diversity, social accountability, and quality control (Gibbons et al., 1994:3-4). Mode 2 can be contextualized with THMI as trilateral networks, university, industry, and government relations (Etzkowitz \& Leydesdorff, 2000:118, 111-112). Mode 3 is a multilateral network by adding a media-based and culture-based public (Carayannis \& Campbell, 2009). With the engagement of society, Mode 3 becomes high-quality democratic knowledge. QuinHMI further strengthened Mode 3 by adding the natural environment as the fifth helix (Carayannis \& Campbell, 2010). Hence, it is recommended to create knowledge with research in terms of Mode 3 and QuinHMI. The green knowledge 
produced by researches together with other modes of knowledge, knowledge created by the university, by the industry, by the state/government, and media-based and culture-based public enjoy the democracy of knowledge driven by the pluralism of knowledge, and these knowledge modes co-exist, co-evolve, and co-specialize with cross integration (Carayannis \& Campbell, 2009). Another critical aspect of the knowledge is knowledge levels, which can be categorized from least to the highest aggregation of knowledge as local, subnational, national, supranational, transnational, and global knowledge. Since sustainability is a global issue that should be addressed locally, green knowledge is termed as glocal (global local) knowledge (Carayannis et al., 2012).

\section{Requisite 06-Community Outreach}

The university and the students cannot be further treated as mere members of mediabased and culture-based public and civil society. They should play the role of active contributors to the broader social, economic, and ecological environment on which all beings are dependent on it. The universities' timely need for engagement with media-based and culture-based public and civil society is now becoming a necessity than ever. Hogner and Kenworthy (2010) pointed out that universities can no longer exist as ivory towers of higher education, which dominated the twentieth-century university educational environment; because of the present age, a need has arisen to engage with the community at multiple levels.

The need for community outreach, the partnership between the community and university, is well described by Boyer (1997:11 cited in Bringle \& Hatcher, 2000). He elaborated that "The academy must become a more vigorous partner in the search for answers to our most pressing social, civic, economic, and moral problems, and must reaffirm its historic commitment to what I call the scholarship of engagement". In ratifying the view abovementioned, Kisker (2007:239) points out that "Collaboration has become pivotal in ensuring quality post-secondary education." Along the same vein, Florence et al. (2007) pointed out that universities, students, and communities significantly value and positively embrace the universitycommunity collaboration in producing knowledge and innovation.

\section{Recommendation 06-Green Community Outreach}

Community outreach is the sixth imperative requisite of a green university. In this regard, it is recommended to set the self-rationale and innovation network as "production of green knowledge and innovation towards green knowledge society and green knowledge democracy." In this respect, it is required to develop a knowledge cluster called "green community outreach" with necessary elements such as green community outreach by faculty, green community outreach by students, Mode 3, QuinHMI in particular media-based and culture-based public including media such as television, internet, newspapers, and culture such as traditions, values. These knowledge cluster elements interact with themselves, and the knowledge cluster interacts with other knowledge clusters creating interdependence. 
It is further recommended to collaborate for sustainable development addressing social problems, but universities are alleged that they are unaware, dated, or disorganized to address constructively for those social problems (Kellogg Commission, 1999). In agreement with the allegation, Bringle and Hatcher (2002:503-504) commented that some universities' outreach programs think of "communities as pockets of needs, laboratories for experimentations, or passive recipients of expertise". However, creating an effective university-community partnership is challenging even though it is an integral part of students' community-based service learning. In meeting the challenges, there are several models now available. Among them, Rinaldi et al. (2018) propose to incorporate community outreach into the "Quadruple Helix model of innovation" developed by Carayannis and Campbell (2009) as the third mission of the university in addition to the first and second mission, teaching and research. QuadHMI recognizes media and the culture-based public and civil society as a pillar of production knowledge and innovation. Universities (even other helices) should communicate their objectives and rationale to the public and seek their legitimacy and justification (Carayannis \& Campbell, 2006a, b:335).

The QuadHMI has been later extended to incorporate natural environment called QuinHMI (Carayannis, \& Campbell, 2010). The QuinHMI enables collaboration with the community for a green lifestyle and learning from their green lifestyles. In this regard, media such as television, the internet, and newspapers could create the capital of information for learning and unlearning traditions and values, as social capital as necessary for sustainable development (Carayannis et al., 2012). When adopting a model, the guiding principle for community outreach is that both parties of the collaboration, university, and the community should work for common interests, responsibilities, privileges, and power to achieve synergies of the partnership (Jacoby, 2003).

\section{Requisite 07-Green Internal Operations/Green Campus}

Universities operate in an internal ecological environment. Its operations in the internal environment have a direct impact on the ecology. The internal ecology of campus for operations contains lands, buildings, vehicles, office equipment, furniture and fittings, tools, and other resources consumed during the operations such as water, electricity, air, and stationery. When consuming these resources in a university's operation, there is a significant impact on the ecology. Sharp (2002), citing Green Building Design Workshop at the University of Michigan, stated buildings globally use $25 \%$ of the global wood harvest, $40 \%$ of the material entering the global economy, $35 \%$ of the total energy consumption, $25 \%$ of the landfill space, and generation of $50 \%$ of the global greenhouse gases and agents of acid rains.

\section{Recommendation 07-Green Internal Operations/Green Campus}

Another imperative requisite of the green university is the green campus/internal operations, which makes greenhouse gas emissions by their operations. In other words, they are also contributors to global environmental issues. Therefore, it is recommended to set the self-rationale and innovation network as "green living internal 
operations for quality of life." In this respect, it is required to develop a knowledge cluster called "green internal operations" with necessary elements such as efficient use of resources (green building, renewable energy, conservation of resources (water/stationery conservation), and internal ecology (green spaces, tree planting). These knowledge cluster elements interact with themselves, and the knowledge cluster interacts with other knowledge clusters creating interdependence. Hence, it is further recommended to have best practices for reducing greenhouse gas emissions and resource conservation in their internal environment by setting an example for their students and other stakeholders. Zhao and Zou (2015) point out that green campus provides "a living environment to help students strengthen their awareness of sustainable development in their daily lives".

\section{Requisite 08-Green (Sustainability) Reporting}

Measuring and reporting sustainable practices is essential to ascertain the progress of performance of goals and objectives set in the strategic plan for the sustainable university's mission and vision. However, measurement is a complex and challenging process for a university, particularly in the early stages of a sustainable university (Gomez et al., 2014). There are many types of tools available for measuring the progress of sustainability. In choosing a tool, the tool's measurement approach is essential for a university, depending on its strategic direction. In general, the approaches used by the tools fall into one of three approaches, namely, account assessments, narrative assessments, and indicator-based assessments. Accounts assessments quantify the university's sustainable practices into monetary values, such as saving energy as a percentage, the payback period of investment in sustainable initiatives. Even though these assessments are useful for financial strategy, they do not represent the main perspectives of the sustainable university (Dalal-Clayton \& Bass, 2002:133). Narrative assessments use texts, maps, graphics, and data specific to the university's sustainable practices. They may use indicators also but not dependent on specifically around the indicators. The major criticism against the narrative assessment is that these assessments lack transparency and consistency, therefore less useful in decision-making and strategy making (Alghamdi et al., 2017). The most widely used sustainability assessment is the indicator-based assessment tools because of their comprehensive nature and representative nature of measuring sustainability despite the diversity of indicators of the tool and various tools used for measuring sustainability (Dalal-Clayton \& Bass, 2002).

\section{Recommendation 08-Sustainability Reporting}

The eighth and last mandatory requisite of the green university is the sustainability reporting. In this regard, it is recommended to set the self-rationale and innovation network as "The quality assurance and feedback mechanism for continuous improvement of the green university system." In this respect, it is required to develop a knowledge cluster called "sustainable reporting" with necessary elements 
such as green corporate governance, green corporate culture, green education, green research, green community outreach, and green internal operations. These knowledge cluster elements interact with themselves, and the knowledge cluster interacts with other knowledge clusters creating interdependence.

It is required to measure the production of green knowledge and innovation, including evaluating the knowledge production process for corrective measures. However, a common weakness of many tools used to measure sustainability is the measure of green organizational structure such as green corporate governance, green corporate culture, green education, green research, green internal operations, green community outreach, and green corporate culture. The values of the culture, such as trustworthiness, equality, respect, and justice, are emerging as the fourth pillar of sustainability (Ribeiro et al., 2016). These kinds of values and beliefs of the sustainability culture could make necessary behavioral changes in the university community by integrating them to achieve sustainable university goals and objectives. Therefore, it is recommended to assess, among other things, the behavioral changes of the university community by pro-sustainability value-based indicators at universities that help to understand their integrity with the sustainable practices of the university relevant (Ribeiro et al., 2016). Levy and Marans (2012) point out that even though universities have published several sustainability reports with selected indicators, none of them had given due attention to cultural issues.

\section{The Integration of Eight Requisites}

As uncovered in the discussion above, what is required is to enable universities to produce glocal green knowledge and innovation in their mainstream knowledge and innovation production system. Since the green knowledge and innovation could be produced with six types of knowledge systems, Mode 1, Mode 2, and Mode 3, THMI, QuadHMI, or superior-quality QuinHMI, the conventional structure of the university should be reconfigured accordingly. In other words, the proposed green university system should enable the contextualization of other knowledge systems. In this regard, eight requisites for reconfiguration were identified as green corporate governance, green corporate culture, three pillars of sustainability, green curriculum, green research, green community outreach, green internal environment, and green reporting.

The integration enables facilitating coexistence and co-evolution of other knowledge paradigms honoring pluralism, knowledge democracy in a KBE. Figure 1 depicts how these eight elements are structured. It is first required to design the green corporate governance structure as the foundation. It is the requisite that provides legitimacy to all other requisites and produces green knowledge with six knowledge production systems. After that, green corporate culture is founded. It is because the green corporate culture can be implanted by the top-down approach, namely, by the diligent efforts of strategic management, which should be complemented by the bottom-up (Schein, 2010). It is then required to design the necessary reconciliation among the three pillars of sustainability (Larson et al., 2013), focusing on local, regional, and global sustainability issues. The reconciliation is, therefore, focused on glocal green knowledge and innovation. The fourth, fifth, sixth, and 
seventh components, green curriculum, green research, green community outreach, and the green internal ecology, are the four battlefields at the beginning in which diverse sustainability practices can be carried out as stipulated by the green governance system. These are battlefields until the university enables producing green knowledge and innovation in its mainstream. The eighth element is to structure the green reporting system to measure if green knowledge and innovation are produced as stipulated by the green governance system through the structure, strategy, and leadership. These eight requisites are interdependent and interact with each other.

\section{Conclusion}

The universities in Botswana still dominate the universities' very purpose that "the pursuit of knowledge for the purpose of knowledge" which motto was set at least at the beginning of the University of Bologna in the twelfth century. It enables producing scientific knowledge without contextualizing with other knowledge systems, in particular, the natural system. Consequently, the conventional Mode 1 is no more adequate to solve social problems for sustainable development meant by the vision 2036 to be a KBE in Botswana. The institutional logics by 2030 Agenda for 17 SDGs, Paris Climate Agreement, Nationally Determined Contribution of Botswana, and the Helix models empower to shift from existing isomorphism to a contemporary isomorphism by contextualizing and producing green knowledge and innovation system with the other knowledge systems, Mode 2; THMI; QuadHMI; in particular, Mode 3; and QuinHMI. These knowledge systems evolve from the knowledge-based society, knowledge-based democracy, and knowledge-based economy to the knowledge society, knowledge democracy, and knowledge economy (Campbell \& Carayannis, 2009: 224).

The universities' stakeholders in Botswana, professors/Drs, senior lecturers, academic managers (Dean/H.O.D.), nonacademic managers, and undergraduates/postgraduates are of the view that the production of green knowledge and innovation is vital. Therefore, the universities' conventional structure should be reconfigured so that the universities enable producing green knowledge and innovation up to the broadest superior level of the knowledge system, Mode 3, and QuinHMI.

According to them, it was found that there are eight knowledge clusters, green corporate governance, green corporate culture, three pillars of sustainability, green education, green research, green community outreach, green internal operations, and green reporting. Each cluster has its own elements organized by its rationale. For example, the rationale of green corporate governance is to provide "the legitimacy for overall governance to create green knowledge and innovation with Mode 3 and QuinHMI." It consists of elements, structure, strategy, and leadership. They are interactive and interdependent. For example, green corporate governance provides legitimacy to all other requisites, and all other requisites entertain the legitimacy and seek further legitimacy when the need arises. Accordingly, each requisite is a knowledge cluster that networks with other knowledge clusters as a network of networks/innovation networks for continuous innovation. 
The eight knowledge clusters were labeled as eight requisites/green university elements to reconfigure the conventional structure. All these eight requisites are imperative. None of them can be ignored. There is a sequence of organizing them, as discussed in Fig. 1. Finally, they were modeled as green university system enabling production green knowledge and innovation with six knowledge systems.

The proposed model depicted in Fig. 1 is useful for universities to ascertain how eight elements of green universities are interactive and interdependent with each other. Further, they can adopt the model to reconfigure their conventional structure to produce green knowledge and innovation with six knowledge systems. The proposed model is useful for policymakers such as the Ministry of Tertiary Education, Botswana Qualification Authority (BQA), to provide and implement policies explicitly encouraging universities to adopt the model. However, the model's insights appear to apply to Botswana and any conventional university around the world. The model was designed empirically. The other researchers can test the model to confirm, vary, contradict, or repudiate the model based on empirical evidence.

However, this study is subject to several limitations. One of the limitations is that the data were collected from a convenience/purposive sample. Hence, the interview sample is related to the conveniently available participants from the population members. Another limitation is that the findings of the study are limited on the analysis of secondary data collected from research articles already published and the primary interview data collected from internal stakeholders of the university system, namely, professors/Drs, senior lecturers, academic managers, nonacademic managers, and undergraduates/postgraduates. The views of the university system's external stakeholders, namely, government, industry, and community/public at large, are also essential but not considered in this study. Another limitation is that the sponsors' views, Ministry of Tertiary Education, the private organizations, and parents were not taken into the study. Their inputs are also important because almost all the students are sponsored students. These limitations provide further research opportunities. Also, there is an opportunity to test the model with quantitative methodology. Further, each requisite also provides an opportunity for future researches.

Abbreviations BQA: Botswana Qualification Authority; ESD: Education for sustainable development; KBEs: Knowledge-based economies; KEI: Knowledge economy index; OECD: Organization for Economic Co-operation and Development; QuadHMI: Quadruple Helix model of innovation; QuinHMI: Quintuple Helix model of innovation; R\&D: Research and development; SDGs: Sustainability development goals; THMI: Triple Helix model of innovation

Author Contribution S.I.H.L. conceived the study for his Ph.D. thesis and drafted the manuscript. F.N. edited the manuscript. Both authors read and approved the final manuscript.

Data Availability Data sharing not applicable to this article as no dataset were generated or analyzed during the current study.

\section{Declarations}

Competing Interests The authors declare that they have no competing interests. 
Disclaimer The contents of this study are solely the opinions of the authors and are not influenced by the funding agencies.

\section{References}

Alghamdi, N., Den Heijer, A., \& De Jonge, H. (2017). Assessment tools' indicators for sustainability in universities: an analytical overview. International Journal of Sustainability in Higher Education, 18(1), 84-115.

Alvesson, M., \& Spicer, A. (2018). Neo-institutional theory and organization studies a mid-life crisis? Organization Studies, 40(2), 199-218. https://doi.org/10.1177/0170840618772610

Arnold G.B. (2004 ). Symbolic politics and institutional boundaries in curriculum reform: The case of National Sectarian University. The Journal of Higher Education, 75 , 572 -593. https://doi.org/10.1353/ jhe.2004.0027

Asongu, S. A., Tchamyou, V. S., \& Acha-Anyi, P. N. (2018). Who is who in knowledge economy in Africa? Journal of Knowledge Economy. https://doi.org/10.1007/s13132-018-0547-8

Baldwin R. G. , \& Baumann M. J. (2005 ). Options for change: A flexible vehicle for curriculum evolution and reform. Innovative Higher Education, 30, 89-98. https://doi.org/10.1007/s10755-005-4958-7

Barth, T. D. (2011). The idea of a green new deal in a Quintuple Helix model of knowledge, know-how, and innovation. International Journal of Social Ecology and Sustainable Development, 1(2), 1-14.

Battilana, J., \& Dorado, S. (2010). Building sustainable hybrid organizations: the case of commercial microfinance organizations. Academy of Management Journal, 53, 1419-1440.

Beer, M., \& Nohria, N. (Eds.) (2000). Breaking the Code of Change. Boston: Harvard Business School Press.

Bessant, S. E. F., Robinson, Z. P., \& Ormerod, R. M. (2015). Neoliberalism, new public management, and the sustainable development agenda of higher education: history, contradictions, and synergies. Environmental Education Research, 21(3), 417-432.

Blackmore P. , \& Kandiko C. B. (2012 ). Processes and resources. In P. Blackmore \& C.B. Kandiko (Eds.), Strategic curriculum change: Global trends in universities (pp. 11 -127). Abingdon, UK : Routledge

Boyce M. E. (2003 ). Organizational learning is essential to achieving and sustaining change in higher education. Innovative Higher Education, 28, 119-136. https://doi.org/10.1023/B:IHIE.0000006287.69207.00

Boyer, E. L. (1997). The scholarship of engagement. Journal of Public Service and Out-Reach, 1(1), 11-20.

Bringle, R. G., \& Hatcher, J. A. (2000). Institutionalization of service-learning in higher education. The Journal of Higher Education, 71(3), 273-290. https://doi.org/10.1080/00221546.2000.11780823

Bringle, R. G., \& Hatcher, J. A. (2002). Campus-community partnerships: the terms of engagement. Journal of Social Issues, 58, 503-516.

Campbell, D. F. J., \& Carayannis, E. G. (2013). Epistemic governance in higher education. Quality enhancement of universities for development. Springer Briefs in Business. New York, NY: Springer. http://www. springer.com/business+\%26+management/organization/book/978-1-4614-4417-6

Carayannis, E. G., \& Alexander, J. M. (2006). Global and local knowledge. Glocal transatlantic publicprivate partnerships for research and technological development. Houndmills.

Carayannis, E. G., Barth T. D., and Campbell, D. F. J. (2012). The Quintuple Helix innovation model: global warming as a challenge and driver for innovation. Journal of Innovation and Entrepreneurship, 1:2. http://www.innovation-entrepreneurship.com/content/1/1/2

Carayannis, E. G, \& Campbell, D. F. J. (2006). In EG Carayannis \& D.F.J. Campbell (Eds.), Knowledge creation, diffusion, and use in innovation networks and knowledge clusters. A comparative systems approach across the United States, Europe, and Asia (pp. 1-25). Westport: Praeger.

Carayannis, E. G., \& Campbell, D. F. J. (2006). 'Mode 3': meaning and implications from a knowledge systems perspective. In G. C. Elias \& D. F. J. Campbell (Eds.), Knowledge Creation, Diffusion, and Use in Innovation Networks and Knowledge Clusters (pp. 1-25). A Comparative Systems Approach across the United States.

Carayannis, E. G., \& Campbell, D. F. J. (2006). Conclusion: key insights and lessons learned for policy and practice. In G. C. Elias \& D. F. J. Campbell (Eds.), Knowledge Creation, Diffusion, and Use in Innovation Networks and Knowledge Clusters (pp. 331-341). A Comparative Systems Approach across the United States.

Carayannis, E. G., \& Campbell, D. F. J. (2009). "Mode 3" and "Quadruple Helix": toward a 21st-century fractal innovation eco-system. International Journal of Technology Management, 46(3/4), 201-234. 
Carayannis, E.G., \& Campbell, D. F. J. (2010). Triple Helix, Quadruple Helix and Quintuple Helix and how do knowledge, innovation, and the environment relate to each other? A proposed framework for a transdisciplinary analysis of sustainable development and social ecology. International Journal of Social Ecology and Sustainable Development, 1(1), 41-69. http://www.igi-global.com/bookstore/article.aspx? titleid $=41959$

Carayannis, E. G., \& Campbell, D. F. J. (2011). Open innovation diplomacy and a 21st-century fractal research, education, and innovation (F.R.E.I.E.) eco-system: building on the Quadruple and Quintuple Helix innovation concepts and the "Mode 3" knowledge production system. Journal of the Knowledge Economy,2(3), 327-372. http://www.springerlink.com/content/d1lr223321305579/

Carayannis, E. G., \& Campbell, D. F. J. \& Rehman, S. S. (2016). Mode 3 knowledge production systems and systems theory, clusters, and networks. Journal of Innovation and Entrepreneurship. 5(17). https://doi. org/10.1186/s13731-016-0045-9

Carayannis, E. G., Grigoroudis, E., Campbell, D. F., Meissner, D., \& Stamati, D. (2018). The eco-system as helix: an exploratory theory-building study of regional co-opetitive entrepreneurial eco-systems as Quadruple/Quintuple Helix Innovation Models. R\&D Management, 48(1), 148-162.

Carayannis, E. G., \& von Zedtwitz, M. (2005). Architecting gloCal (global-local), real-virtual incubator networks (G-RVINs) as catalysts and accelerators of entrepreneurship in transitioning and developing economies. Technovation, 25, 95-110.

Cartwright, W., \& Craig, J. L. (2006). Sustainability: aligning corporate governance, strategy, and operations with the planet. Business Process Management Journal, 12(6), 741-750.

Chin, A., Chu. J., Perera, M., Hui, K., Yen. H. L., Chan, M., Peiris, M., \& Poon, L. (2020). Stability of SARSCoV-2 in different environmental conditions. medRxiv

Dalal-Clayton, B., \& Bass, S. (Eds.). (2002). Sustainable development strategies. Earthscan.

De Ciurana, A. M. G., \& Filho, W. L. (2006). Education for sustainability in university studies: experiences from a project involving European and Latin American universities. International Journal of Sustainability in Higher Education, 7(1), 81-93.

Dill, D. (1997). Higher Education Markets and Public Policy. Higher Education Policy, 10(3-4), 167-185.

DiMaggio, P. J., \& Powell, W. W. (1983). The iron cage revisited: institutional isomorphism and the collective rationality in organizational fields. American Sociological Review, 48(2), 147-160.

Di Nauta, P., Merola, B., Caputo, F. \& Federica Evangelista, F. (2015). Reflections on the role of university to face the challenges of knowledge society for the local economic development. Journal of Knowledge Economy. https://doi.org/10.1007/s13132-015-0333-9

Doppelt, B. (2010). Leading change toward sustainability: a change management guide for business, government, and civil society. Greenleaf Publishing.

Dubina, I. N., Carayannis, E. G., \& Campbell, D. F. J. (2012). Creativity economy and a crisis of the economy? Co-evolution of knowledge, innovation, and creativity, and of the knowledge economy and knowledge society. Journal of the Knowledge Economy, 3(1), 1-24.

Eckel P. D., \& Kezar A. J. (2002 ). The effect of institutional culture on change strategies in higher education: Universal principles or culturally responsive concepts? The Journal of Higher Education, 73, 435-460. https://doi.org/10.1353/jhe.2002.0038

Etzkowitz, H., \& Leydesdorff, L. (1995). The Triple Helix - university-industry-government relations: a laboratory for knowledge based economic development. E.A.S.S.T. Review, 14, 14-19.

Etzkowitz, H., \& Leydesdorff, L. (2000). The dynamics of innovation: from national systems and "mode 2" to a triple helix of university-industry-government relations. Research Policy, 29(2), 109-123.

Etzkowitz, H. (2003). Innovation in Innovation: The Triple Helix of University-Industry-Government Relations. Social Science Information., 42(3), 293-337. https://doi.org/10.1177/05390184030423002

Florence, J., Goodrow, B., Wachs, J., Grover, S., \& Olive, K. (2007). Rural health professions education at East Tennessee University: survey of graduates from the first decade of the community partnership program. The Journal of Rural Health., 23(1), 77-83.

Fonseca, A., Macdonald, A., Dandy, E., \& Valenti, P. (2011). The state of sustainability reporting at Canadian universities. International Journal of Sustainability in Higher Education, 12(1), 22-40.

Galpin, T., Whitttington, J. L., \& Bell, G. (2015). Is your sustainability strategy sustainable? Creating a culture of sustainability. Corporate Governance., 15(1), 1-17.

George, E.S. (2006). Positioning higher education for the knowledge based economy. High Educ, 52(589). https://doi.org/10.1007/s10734-005-0955-0

Gibbons, M., Limoges, C., Nowotny, H., Schwartzman, S., Scott, P., \& Trow, M. (1994). The new production of knowledge. The dynamics of science and research in contemporary societies. Sage. 
Ginzel, L. E., Kramer, R. M., \& Sutton, R. I. (1992). Organizational impression management as a reciprocal influence process: The neglected role of the organizational audience. In L. L. Cummings \& B. M. Staw (Eds.), Research in Organizational Behavior, vol. 14: 227-266. Greenwich, CT: JAI Press.

Goodrick, E., \& Reay, T. (2011). Constellation of instittuional logics: changes in the professional work of pharmacists. Work and Occupations, 38(3), 372-416.

Gomez, F., Sáez-Navarrete, C., Lioi, S. \& Marzuca, V. (2014). Adaptable model for assessing sustainability in higher education. Journal of Cleaner Production. www.sciencedirect.com/science/article/pii/ S0959652614007641

Gough, D, Oliver, S, Thomas, J (2017) An introduction to systematic reviews. 2nd edition. London: Sage Publications Ltd, 304 pages. ISBN: 9781849201810

Grundel, I., \& Dahlström, M. (2016). A Quadruple and Quintuple Helix approach to regional innovation systems in the transformation to a forestry-based bioeconomy. Journal of Knowledge Economy., 7, 963983. https://doi.org/10.1007/s13132-016-0411-7

Henkel, M. (2007). "Can Academic Autonomy Survive in the Knowledge Society? A Perspective from Britain." Higher Education Research \& Development, 26(1), 87-99

Higgins, B., \& Thomas, I. (2016). Education for sustainability in universities: challenges and opportunities for change. Australian Journal of Environmental Education., 32(1), 91-108.

Hira, A., \& Hira, R. (2010). New institutionalism and change. American Journal of Economics and Sociology, 59(2), 267-282. https://doi.org/10.1111/1536-7150.00026

Hogner, R. H., \& Kenworthy, A. L. (2010). Moving forward together in sustainable, effective, and partnership-oriented ways: connecting universities and communities through global leadership service projects. International Journal of Organizational Analysis, 18(2), 245-266.

Institute of Directors. (2016). King IV report on Corporate Governance for South Africa. https://c.ymcdn.com/ sites/iodsa.site-ym.com/resource/collection/684B68A7-B768-465C-8214E3A007F15A5A/IoDSA_ King_IV_Report_-_WebVersion.pdf

Jacoby, B. (2003). Fundamentals of service-learning partnerships. in Jacoby, B. and Associates (Eds), Building Partnerships for Service-learning. Wiley, San Francisco, CA, pp. 1-19

Jorge, M. A., Madueño, J. H., Calzado, Y., \& Andrades, J. (2016). A proposal for measuring sustainability in universities: a case study of Spain. International Journal of Sustainability in Higher Education., 17(5), 671-697.

Kajikawa, Y. (2008). Research core and framework of sustainability science. Sustain Sci. 3(215). https://doi. org/10.1007/s11625-008-0053-1

Kellogg Commission. (1999). Returning to our roots: the engaged institution. Washington, DC: National Association of State Universities and Land Grant Colleges. http://www.aplu.org/library/returning-to-ourroots-the-engaged-institution/file.pdf

Kisker, C. (2007). Creating and sustaining community college: university transfer partnerships. Community College Review, 34(4), 282-301.

Klettner, A., Clarke, T., \& Boersma, M. (2014). The governance of corporate sustainability: empirical insights into the development, leadership and implementation of responsible business strategy. Journal of Business Ethics, 122, 145-165.

Kolehmainen, J., Irvine, J., Stewart, L., Karacsonyi, Z., Szabó, T., Alarinta, J., \& Norberg, A. (2016). Quadruple Helix, innovation and the knowledge-based development: lessons from remote, rural and lessfavoured regions. Journal of Knowledge Economy, 7, 23-42.

Knoema. (2019). Knowledge economy index, World Bank. https://knoema.com/WBKEI2013/knowledgeeconomy-index-world-bank-discontinued

Larson, K. L., Wiek, A., \& Withycombe, K. L. (2013). A comprehensive sustainability appraisal of water governance in Phoenix AZ. Journal of Environmental Management, 116(1), 58-71.

Lee, D., Kang, J., \& Kim, K. (2020). Global collaboration research strategies for sustainability in the post COVID-19 era: Analyzing virology-related national-funded projects. Sustainability (Switzerland), 12(16). https://doi.org/10.3390/su12166561

Levy, B. L. M., \& Marans, R. W. (2012). Towards a campus culture of environmental sustainability: recommendations for a large university. International Journal of Sustainability in Higher Education, 13(4), 365-377.

Leydesdorff, L. (2012). The Triple Helix, Quadruple Helix, and an N-Tuple of Helices: explanatory models for analyzing the knowledge-based economy? Journal of Knowledge Economy, 3, 25-35. https://doi. org/10.1007/s13132-011-0049-4

Lozano, R. (2006). Incorporation and institutionalization of S.D. into universities: breaking through barriers to change. Journal of Cleaner Production, 14(9/11), 787-796. 
Mandal, C. C., \& Panwar, M. (2020). Can the summer temperatures reduce COVID-19 cases? Public Health, 185, 72-79.

Martin, B. R. (2016). What's happening to our universities? Prometheus, 34(1), 7-24. https://doi. org/10.1080/08109028.2016.1222123

McPherson, C. M., \& Sauder, M. (2013). Logics in action: Managing institutional complexity in a drug court. Administrative Science Quarterly, 58(2), 165-196. https://doi.org/10.1177/0001839213486447

Mendivil, J. L. I. (2002). The New Providers of Higher Education. Higher Education Policy, 15, 353-364.

Mensah, M. S. B., \& Enu-Kwesi, F., \& Rosemond Boohene, R. (2017) Challenges of Research Collaboration in Ghana's Knowledge-based Economy. Journal of Knowledge Economy. https://doi.org/10.1007/s13132017-0450-8

Merton P., Froyd J. E., Clark M. C., \& Richardson, J. (2009). A case study of relationships between organizational culture and curricular change in engineering education. Innovation in Higher Education, 34, 219-233. https://doi.org/10.1007/s10755-009-9114-3

Meyer, J., \& Rowan, B. W. (1977). Institutionalized organizations: formal structure, myth and ceremony. American Journal of Sociology, 83, 340-361.

Mulder, P., \& Van Den Bergh, J. C. (2001). Evolutionary economic theories of sustainable development. Growth and Change, 32, 110-134. https://doi.org/10.1111/0017-4815.00152

Neilsen, E. H., \& Rao, M. V. H. (1987). The strategy-legitimacy nexus: A thick description. Academy of Management Review, 12, 523-533.

Nowotny, H., Scott, P., \& Gibbons, M. (2001). Re-thinking science. Knowledge and the public in an age of uncertainty. Polity Press.

Nowotny, H., Scott, P., \& Gibbons, M. (2003). Mode 2 revisited: the new production of knowledge. Minerva, 41, 179-194.

Nowotny, H., Scott, P., \& Gibbons, M. (2006). Re-thinking science: mode 2 in societal context. In E. G. Carayannis \& D. F. J. Campbell (Eds.), Knowledge creation, diffusion, and use in innovation networks and knowledge clusters. A Comparative Systems Approach Across the United States, Europe and Asia (pp. 39-51). Westport, Connecticut: Praeger

OECD. (1996). The Knowledge-based Economy. OECD/GD, 102, 1-46.

Onyancha, O. B., \& Maluleka, J. R. (2011). Knowledge production through collaborative research in sub-Saharan Africa: how much do countries contribute to each other's knowledge output and citation impact? Scientometrics, 87, 315-336. https://doi.org/10.1007/s11192-010-0330-5

Ott, K. (2003). The case for strong sustainability. in Ott, K. and Thapa, P. (Eds), Greifswald's Environmental Ethics. Steinbecker Verlag Ulrich Rose, Greifswald

Perrow, C. (1970). Organizational analysis: A sociological view. Belmont, CA: Wadsworth.

Pollock, N., Horn, E., Costanza, R., \& Sayre, M. (2009). Envisioning helps promote sustainability in academia, a case study at the University of Vermont. International Journal of Sustainability in Higher Education., $10(4), 343-353$.

Pratt, J. (2004) Institutional isomorphism and online learning in Australian higher education , Academy of World Business. Marketing and Management Development Conference, Gold Coast, Queensland, July 13-16

Ribeiro, M. M., Hoover, E., Burford, G., Buchebner, J., \& Lindenthal, T. (2016). Values as a bridge between sustainability and institutional assessment: a case study from B.O.K.U. University. International Journal of Sustainability in Higher Education, 17(1), 40-53.

Rinaldi, C., Cavicchi, A., Spigarelli, F., Lacchè, L., \& Rubens, A. (2018). Universities and smart specialisation strategy: from third mission to sustainable development co-creation. International Journal of Sustainability in Higher Education, 19(1), 67-84. https://doi.org/10.1108/IJSHE-04-2016-0070

Schein, E. H. (1992). Organizational culture and leadership. Jossey-Bass.

Schein, E. H. (Ed.). (2010). Organizational culture and leadership. Jossey-Bass.

Scott, W. R. (1987). The adolescence of institutional theory. Administrative Science Quarterly, 32, $493-511$.

Sharp, L. (2002). Green campuses: the road from little victories to systemic transformation. International Journal of Sustainability in Higher Education., 3(2), 128-145.

Smith, P. A. C. (2011). Guest editorial: elements of organizational sustainability. The Learning Organization., 18(1), 5-9.

Suchman, M. (1995). Managing legitimacy: strategic and institutional approaches. Academy of Management Review, 20, 571-610.

Svarc, J., \& Dabic, M. (2017). Evolution of the knowledge economy: a historical perspective with an application to the case of Europe. Journal of Knowledge Economy, 8, 159-176. https://doi. org/10.1007/s13132-015-0267-2 
Thaman, K. H. (2002). Shifting sights: the cultural challenge of sustainability. International Journal of Sustainability in Higher Education, 3(3), 233-242. https://doi.org/10.1108/14676370210434697

The Conversation. (2020). Hacking the pandemic: how Taiwan's digital democracy holds Covid-19 at bay. https://theconversation.com/hacking-the-pandemic-how-taiwans-digital-democracy-holds-covid19-at-bay-145023

Thornton, P. H., Ocasio, W., \& Lounsbury, M. (2012). The institutional logics perspective: a new approach to culture, structure, and process. Oxford University Press.

Tiba, S. \& Frikha M. (2018). Africa is rich, Africans are poor! A blessing or curse: an application of cointegration techniques. Journal of the Knowledge Economy. https://doi.org/10.1007/s13132018-0538-9

Torraco, R. J. (2005). Organization development: a question of fit for universities. Advances in Developing Human Resources., 7(3), 303-310.

Velazquez, L., Munguia, N., Platt, A., \& Taddei, J. (2006). Sustainable university: what can be the matter? Journal of Cleaner Production., 14, 810-819.

Waldorff, S. B., Reay, T., \& Goodrick, E. (2013). A tale of two countries: how different constellations of logics impact action. In M. Lounsbury \& E. Boxenbaum (Eds.), Institutional logics in action, Research in the Sociology of Organizations, 39(A) (pp. 99-129). Emerald Press.

Webber, M. (1952). The Protestant ethics and the spirit of capitalism. Scribner.

World Health Organization. (2020). Water, sanitation, hygiene and waste management for COVID-19: technical brief, 03 March 2020.

World Summit United Nations General Assembly. (2005). World Summit Outcome, Resolution A/60/1, adopted by the General Assembly, 15 September 2005

Wright, T. (2010). University presidents' conceptualizations of sustainability in higher education. International Journal of Sustainability in Higher Education., 11(1), 61-73.

Zhao, W., \& Zou, Y. (2015). Green university initiatives in China: a case of Tsinghua University. International Journal of Sustainability in Higher Education., 16(4), 491-506.

Zucker, L. (1977). The role of institutionalization in cultural persistence. American Sociological Review, 42(5), 726-743. Retrieved from www.jstor.org/stable/2094862

Publisher's Note Springer Nature remains neutral with regard to jurisdictional claims in published maps and institutional affiliations.

\section{Authors and Affiliations}

\section{Shantha Indrajith Hikkaduwa Liyanage ${ }^{1}$ (D) Fulu Godfrey Netswera ${ }^{2}$}

Fulu Godfrey Netswera

FulufheloN@dut.ac.za

1 Botho University, Gaborone, Botswana

2 Durban University of Technology, Durban, South Africa 